\title{
Dynamic paraspeckle component localisation during spermatogenesis
}

\author{
Andrew T Major ${ }^{1,2}$, Cathryn A Hogarth ${ }^{2,3}$, Julia C Young ${ }^{1,2}$, Yasuyuki Kurihara4, David A Jans ${ }^{2,5}$ \\ and Kate L Loveland ${ }^{1,2,5,6,7}$ \\ ${ }^{1}$ Department of Anatomy and Developmental Biology, Monash University, Melbourne, Australia, ${ }^{2}$ The ARC Centre \\ of Excellence in Biotechnology and Development, Melbourne, Australia, ${ }^{3}$ Department of Pharmacy and Biomedical \\ Sciences, La Trobe University, Albury-Wodonga, Australia, ${ }^{4}$ Faculty of Engineering Science, Yokohama National \\ University, Yokohama, Japan, ${ }^{5}$ Department of Biochemistry and Molecular Biology, Monash University, Melbourne, \\ Australia, ${ }^{6}$ Centre for Reproductive Health, Hudson Institute of Medical Research, Melbourne, Australia and ${ }^{7}$ School \\ of Clinical Sciences, Monash University, Melbourne, Australia
}

Correspondence should be addressed to K L Loveland; Email: Kate.Loveland@monash.edu

\begin{abstract}
Expression profiles and subcellular localisations of core Drosophila behaviour/human splicing (DBHS) proteins (PSPC1, SFPQ and NONO) and NEAT1, a long noncoding RNA (IncRNA), are investigated in developing and adult mouse testes. Core DBHS proteins are markers for the distinct subnuclear domain termed paraspeckles, while a long NEAT1 isoform scaffold facilitates paraspeckle nucleation. Paraspeckles contain many proteins ( $>40)$ and are broadly involved in RNA metabolism, including transcriptional regulation by protein sequestration, nuclear retention of A-to-I edited RNA transcripts to regulate translation and promoting survival during cellular stress. Immunohistochemistry reveals cell-specific profiles for core DBHS paraspeckle protein expression, indicating their functional diversity. PSPC1 is an androgen receptor co-activator, and it is detected in differentiating Sertoli cell nuclei from day 15 onwards, as they develop androgen responsiveness. PSPC1 is nuclear in the most mature male germ cell type present at each age, from foetal to adult life. In adult mouse testes, PSPC1 and SFPQ are present in Sertoli cells, spermatocytes and round spermatids, while the NEAT1 IncRNA appears in the punctate nuclear foci delineating paraspeckles only within Leydig cells. Identification of NEAT1 in the cytoplasm of spermatogonia and spermatocytes must reflect non-paraspeckle-related functions. NONO was absent from germ cells but nuclear in Sertoli cells. Reciprocal nuclear profiles of PSPC1 and $\gamma-\mathrm{H} 2 \mathrm{AX}$ in spermatogenic cells suggest that each performs developmentally regulated roles in stress responses. These findings demonstrate paraspeckles and paraspeckle-related proteins contribute to diverse functions during testis development and spermatogenesis.

Reproduction (2019) 158 267-280
\end{abstract}

\section{Introduction}

The nucleus contains many distinct subnuclear domains, such as the nucleolus, Cajal bodies, PML bodies and nuclear speckles, each of which performs functions without lipid bilayer membrane enclosure. One of the most recently discovered subnuclear domains is the paraspeckle(Foxetal. 2002). We previously demonstrated that regulated expression of certain nuclear transport machinery allows stage-specific protein access to the nucleus during spermatogenesis (reviewed in Major et al. 2011, Miyamoto et al. 2012, Loveland et al. 2015). A core component of the paraspeckle, paraspeckle protein 1 (PSPC1), is a developmentally regulated cargo of the nucleocytoplasmic transporter, importin alpha 2 (IMP $\alpha 2$ ), in the foetal mouse testis (Major et al. 2015, 2017). Here we examine the expression profiles of PSCP1 and the other core-associated paraspeckle components throughout mouse spermatogenesis, to determine whether these are also developmentally regulated and to explore the hypothesis that their coordinated synthesis would be required for paraspeckle functions.

Paraspeckles are a distinct subnuclear domain rich in RNA-binding proteins and RNA transcripts, particularly those which are A-to-I edited, coalescing to form what West et al. (2016) described as a 'characteristic coreshell spheroidal' structure when analysed using superresolution microscopy. These are built upon the IncRNA nuclear paraspeckle assembly transcript 1 (NEAT1), formerly known as nuclear-enriched abundant transcript 1. In addition to the three core Drosophila behaviour, human splicing (DBHS) paraspeckle proteins, PSPC1, SFPQ and NONO (Fox et al. 2002), over 60 other protein components are identified as potentially localising to paraspeckles (Naganuma et al. 2012, Fong et al. 2013). DBHS proteins have other nuclear functions outside of paraspeckles relating to RNA production and processing, 
including transcriptional initiation/termination, splicing, polyadenylation and mRNA transport (Patton et al. 1993, Gozani et al. 1994, Peng et al. 2002, Shav-Tal \& Zipori 2002, Kameoka et al. 2004, Kanai et al. 2004, Rosonina et al. 2005, Liang \& Lutz 2006, Kaneko et al. 2007, Ito et al. 2008, Izumi et al. 2014, Lu \& Sewer 2015). Although their roles are central to cellular functions, their contribution to spermatogenesis remains to be determined.

The IncRNA NEAT1 is a crucial paraspeckle component, serving as the nucleation scaffold which allows co-assembly of other paraspeckle components (Bond \& Fox 2009, Chen \& Carmichael 2009, Clemson et al. 2009, Sasaki et al. 2009, Sunwoo et al. 2009). The NEAT1 transcript has two isoforms that are encoded in the genome without introns; the shorter variant is termed NEAT1_1/MEN $\varepsilon$ (3.2 kb (mouse); $3.7 \mathrm{~kb}$ (human)), and a longer variant is NEAT1_2/MEN $\beta$ (20.8 kb (mouse); $22.7 \mathrm{~kb}$ (human)) (Sunwoo et al. 2009, Naganuma \& Hirose 2013). Unlike many noncoding RNAs, NEAT1_1 is highly conserved in mammals (Sunwoo et al. 2009). The $3^{\prime}$ end of NEAT1_1 contains a poly(A) tail. In contrast, the NEAT1_2 transcript encodes a triple helix structure at its $3^{\prime}$ end proposed to stabilise the transcript (Brown et al. 2012, Wilusz et al. 2012); it is initially synthesised with a tRNA-like small RNA sequence that is cleaved off by RNase P to yield the mature 3'end (Sunwoo et al. 2009). Both NEAT1 transcripts can localise to paraspeckles (Souquere et al. 2010), but the longer NEAT1_2 transcript is essential for paraspeckle nucleation (Naganuma et al. 2012). The shorter NEAT1_1 transcript is also implicated in transcriptional regulation by enhancing active chromatin states of specific promoters (Chakravarty et al. 2014, Li et al. 2017).

PSPC1 is produced in two isoforms. The longer variant is highly abundant in the mammalian testis, associated with the nuclear matrix, and has proposed roles in chromatin remodelling during spermatogenesis (Myojin et al. 2004). PSPC1 can complex with SFPQ or NONO in an immortalised Sertoli cell line, TTE3; over-expression of each component enhanced androgen receptormediated translation, with PSPC1 eliciting the largest response (Kuwahara et al. 2006). In photobleaching experiments using HeLa cells, PSPC1 is predominantly localised to paraspeckles, but demonstrated to shuttle between paraspeckles and the nucleolus (Fox et al. 2002). When transcription is inhibited, PSPC1 relocates from paraspeckles to the nucleolar caps (Fox et al. 2002, 2005); this process also occurs naturally for a brief window during telophase, before transcription recommences (Fox et al. 2005). In cultured cells, PSPC1 has been implicated in the DNA damage response through regulation of the G1/S checkpoint, effectively halting the cell cycle to allow DNA repair; siRNA knockdown of PSPC1 results in G1/S checkpoint escape and increased cellular death rates (Gao et al. 2014). PSPC1 has also been implicated in the promotion of epithelial-to-mesenchymal transition (EMT), stemness and metastasis through transforming growth factor $\beta 1$ (TGF- $\beta 1$ ) autocrine signalling and Smad2/3 target switching (Yeh et al. 2018).

Broad roles of SFPQ include splicing, transcription, translation, DNA repair, sister chromatid cohesion and apoptosis (see Yarosh et al. 2015 for review). NONO contributes to mammalian circadian rhythms (Brown et al. 2005) and links the circadian clock and cell cycles (Kowalska et al. 2013, Maier \& Kramer 2013), while other DBHS proteins may serve redundant or overlapping roles at circadian-regulated genes as transcriptional cofactors (Kowalska et al. 2012). In addition, the DBHS proteins are each implicated in DNA double-strand break repair, a process central to spermatogenesis (Bladen et al. 2005, Li et al. 2009, 2014, Ha et al. 2011, Rajesh et al. 2011, Gao et al. 2014).

The functional significance of paraspeckles remains under investigation, with diverse functions now proposed and demonstrated. Paraspeckles can suppress translation by facilitating the nuclear retention of A-to-I edited RNA transcripts (Zhang \& Carmichael 2001, Prasanth et al. 2005), regulate transcription by sequestering proteins (Hirose et al. 2014) and have been implicated in the first stages of miRNA biogenesis (Jiang et al. 2017, Krol 2017). Importantly, NEAT1 levels inversely correlate with sensitivity to stress-induced apoptosis in studies of mouse embryonic fibroblasts (Hirose et al. 2014) and is directly correlated with various types of cancer cells (in which it is elevated), including breast (Choudhry et al. 2015), cervical (Wang \& Zhu 2018), colorectal (Li et al. 2015, Wu et al. 2015), glioma (He et al. 2016), leukaemia (Zeng et al. 2014, Blume et al. 2015), liver (Guo et al. 2015), lung (You et al. 2014, Zhao et al. 2014, Pan et al. 2015, Hu et al. 2016) and prostate (Chakravarty et al. 2014).

Despite the important roles that paraspeckles and their components play during normal development and in diseases such as cancer and amyotrophic lateral sclerosis (Nishimoto et al. 2013, Shelkovnikova et al. 2014, 2018), characterisation of paraspeckle components during normal developmental processes has been limited. Given that core DBHS paraspeckle proteins are present in the adult testis (Kuwahara et al. 2006), with PSPC1 highly abundant (Myojin et al. 2004), the spatial-temporal expression patterns of these proteins and NEAT1 (Fig. 1) is interrogated in mouse testis throughout development in this study. This information sheds light on how these proteins and the formation of paraspeckles may influence spermatogenesis and the processes essential for male fertility.

\section{Materials and methods}

\section{Animals and tissue sample preparation}

Postnatal testes were obtained from Swiss and C57/BL6xCBA outbred male mice, while foetal testes and ovaries were 


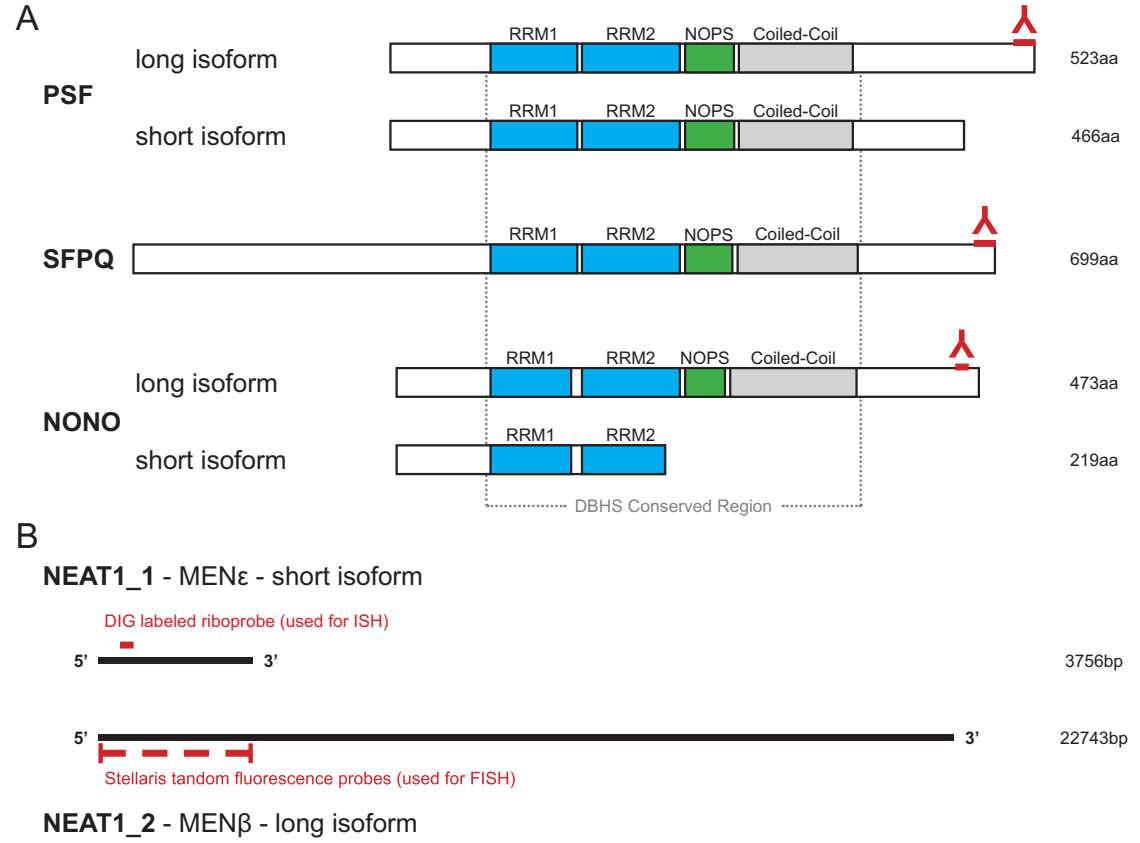

Figure 1 Core paraspeckle components in the mouse. (A) The core paraspeckle DBHS proteins (PSPC1, PSF and NONO) are shown with long and short variants, the conserved domains. The regions of these proteins targeted by antibodies used in this study are indicated (in red). (B) The two splice variants of NEAT1 long noncoding RNA are shown with the region used to generate a DIGlabelled riboprobe (ISH) highlighted in red, while the Stellaris probe (FISH) is a pool of fluorescently labelled probes along the length of the 5'region, shared by long (NEAT1_2) and short (NEAT1_1) transcripts (red dotted line). collected from embryos staged by fore- and hindlimb morphology from time-mated pregnant Swiss female mice from Monash University. All investigations conformed to the NHMRC/CSIRO/AAC Code of Practice for the Care and Use of Animals for Experimental Purposes and were approved by the Monash University Standing Committee on Ethics in Animal Experimentation. Tissues for immunohistochemistry were fixed in Bouins fixative for $5 \mathrm{~h}$, dehydrated through graded ethanols, paraffin embedded and sectioned $(3-5 \mu \mathrm{m})$ using standard protocols (Loveland et al. 1999).

\section{Immunohistochemistry}

Immunohistochemistry with anti-PSPC1, anti-NONO and anti-SFPQ (Kuwahara et al. 2006) mouse monoclonal antibodies (mAbs) was performed as previously (Loveland et al. 1999) using $50 \mathrm{mM}$ glycine for antigen retrieval $(\mathrm{pH} 3.5$; $>90^{\circ} \mathrm{C}$ for $\left.8 \mathrm{~min}\right)$, and diluted primary antibodies $(0.1 \%$ BSA/TBS) for $\mathrm{O} / \mathrm{N}$ incubation at RT. Control sections lacked primary antibody. Secondary antibody incubations (1:500 in $0.1 \% \mathrm{BSA} / \mathrm{TBS}, 1 \mathrm{~h}$ ), rabbit anti-mouse antibody (DAKO, E0354), were followed by incubation with Vectastain Elite $\mathrm{ABC}$ kit reagent (Vector Laboratories, distributed by Abacus Als, Waterford, Australia). Antibody binding was detected as a brown precipitate following development with $0.20 \mathrm{mg} / \mathrm{mL}$ 3,3'-diaminobenzidine tetrahydrochloride (Sigma-Aldrich). Harris Haematoxylin counterstain (Sigma-Aldrich) and DPX Mountant (Sigma-Aldrich) were applied. Germ and somatic cell types were identified based on nuclear morphology and position within the developing gonad (Byskov 1986, Russell 1990).

\section{In situ hybridisations}

In situ hybridisations were performed with $300 \mathrm{ng}$ of DIG-labelled NEAT1 riboprobe at $55^{\circ} \mathrm{C}$ as previously
(Meehan et al. 2000). Briefly, the $324 \mathrm{nt}$ segment of mouse NEAT1 (accession numbers in Supplementary Table S1) was amplified using the primers (forward: 5'-CGCTGGGCGGACAGCTCTGG-3', reverse: 5'-ACCGGACGACCCAGGGGCAA-3'), ligated into the pGEMT Easy vector (Promega) and the DIG-labelled sense/ anti-sense riboprobes generated using T7 and Sp6 RNA polymerases. After $\mathrm{O} / \mathrm{N}$ hybridisation, probe binding was detected using an alkaline phosphatise-conjugated anti-DIG antibody and enzymatic conversion of the NBT/BCIP Substrate Solution (Thermo Scientific) to form an insoluble brownpurple precipitate. Sections were mounted under coverslips with GVA (Zymed-Invitrogen), and then slides were imaged using a Zeiss Axio Imager A1 fitted with a $20 \times$ objective and an AxioCam MRc5 camera (Carl Zeiss).

\section{Northern blot}

Northern blots using DIG-labelled riboprobes were performed as previously described (Hogarth et al. 2006). Briefly, total RNA from adult mouse testis, kidney and liver were extracted using TRIzol (Thermo Scientific) as per manufacturer's instructions and resuspended in deionised formamide. Sample concentrations were estimated with a NanoDrop 2000 Spectrophotometer (Thermo Scientific) and $30 \mu \mathrm{g}$ loaded per lane with a RiboRuler High Range RNA Ladder (Thermo Scientific) before electrophoretic separation through a formaldehyde agarose gel. Separated samples were transferred to Amersham Hybond XL membrane (GE Life Sciences). Membranes were blocked in Ambion ULTRAhyb (Thermo Scientific) at $68^{\circ} \mathrm{C}$ for $1 \mathrm{~h}$, before applying DIG-labelled riboprobe $\left(100 \mathrm{ng} / \mathrm{mL}, 68^{\circ} \mathrm{C}, \mathrm{O} / \mathrm{N}\right.$ with rotary agitation). Membranes were then washed $0.1 \%$ SSC and $0.1 \%$ SDS at $68^{\circ} \mathrm{C}$, and then in maleic acid buffer $(0.1 \mathrm{M}$ maleic acid with $0.15 \mathrm{M} \mathrm{NaCl}, \mathrm{pH} 7.5$, and $0.3 \%$ Tween). The bound probe was detected using an alkaline phosphataseconjugated anti-DIG antibody (1:10,000, Roche Molecular 
Biochemicals) to create a chemiluminescent signal which was captured on film after the addition of CDP-STAR substrate (Roche Molecular Biochemicals).

\section{FISH/IF}

FISH to detect NEAT1 transcript was performed with a Stellaris FISH Probe (Biosearch Technologies, Petaluma, USA) to mouse NEAT1 5' segment (labelled with Quasar 570 Dye, SMF-3009-1) as per the manufacturer's instructions on mouse testis tissue sections prepared as above or on GC-1 and GC-2 cells. GC-1 and GC-2 were grown in DMEM (supplemented with $10 \%$ (v/v) foetal calf serum, PenicillinStreptomycin (Pen-Strep), L-Glutamine and MEM non-essential amino acids) with $5 \% \mathrm{CO}_{2}$ at $37^{\circ} \mathrm{C}$ on glass coverslips, and then fixed in $3.7 \%$ formaldehyde (10 min @ RT). All buffers were prepared using diethylpyrocarbonate (DEPC)-treated Milli-Q water (Merck Millipore). Cells on coverslips and tissue sections (post-rehydration) were permeabilised in $70 \%$ $\mathrm{v} / \mathrm{v}$ ethanol for $1-2 \mathrm{~h}$ before performing FISH hybridisation for $16 \mathrm{~h}$ at $37^{\circ} \mathrm{C}$. After washing and incubating with DAPI (4',6-diamidino-2-phenylindole, dilactate; Thermo Scientific), samples were mounted with GVA (Genemed Biotechnologies, South San Francisco, USA) or those samples undergoing subsequent immunofluorescence (for FISH/IF) were fixed with 4\% paraformaldehyde (15 min @ RT). For the remaining immunofluorescence steps, PBS was used throughout. Samples were washed, blocked with $0.5 \%$ BSA and primary antibody added (mouse mAb to PSPC1; Kuwahara et al. 2006, 1:100 in 0.5\% BSA, $1 \mathrm{~h} @$ RT). Samples were washed, and secondary antibodies added (goat anti-mouse, Alexa Fluor 488, Molecular Probes - Thermo Scientific, 1:500, 0.5\% BSA, $1 \mathrm{~h} @ \mathrm{RT})$. After final washes, samples were mounted with GVA (Genemed Biotechnologies) and imaged using a Leica SP5 laser scanning confocal system (DMI6000 microscope, motorised stage, $63 \times$ water/glycerol objective, Monash Micro Imaging Facility). Images were collected as Z-series and later merged to form 2D maximum intensity projections.

Co-immunofluorescence for PSPC1 and $\gamma$ - $22 A X$ was performed on rehydrated adult mouse tissue sections essentially using immunofluorescence and imaging steps described above, with minor modifications as follows. Sections were permeabilised in $0.2 \%$ Triton $\mathrm{X}-100$ for $30 \mathrm{~min}$ prior to blocking. Primary antibodies (mouse mAb to PSPC1, 1:100, Kuwahara et al. 2006; rabbit anti- $\gamma-\mathrm{H} 2 \mathrm{AX}, 1: 100$, AbCam, ab11174) were incubated $\mathrm{O} / \mathrm{N}$ at RT and secondary antibodies (donkey anti-mouse Alexa Fluor 488, 1:500; goat anti-rabbit Alexa fluor 546, 1:500 (Molecular Probes - Thermo Scientific)) with DAPI (Thermo Scientific) were incubated for $90 \mathrm{~min}$.

\section{Western blotting}

Samples were homogenised using a graded needle series in RIPA buffer (150 mM NaCl, 1\% NP-40, 0.5\% Tween-20, 0.1\% SDS, $1 \mathrm{mM}$ EDTA, $50 \mathrm{mM}$ Tris) with protease inhibitor cocktail (1:500, Set III, Calbiochem - Merck Millipore) at $4^{\circ} \mathrm{C}$, and insoluble material was removed by centrifugation $(20,000 \mathrm{~g}$, 20 min @ $4^{\circ} \mathrm{C}$ ). Protein concentrations were estimated using DC Protein Quant Assay (BioRad) against a bovine serum albumin
(BSA) standard. Lysates $(50 \mu \mathrm{g}$ per lane) were mixed with $2 \times$ sample buffer, run on $12 \%$ SDS-PAGE gels with protein size standards (PageRuler Prestained Protein Ladder; FermentasThermo Scientific), transferred to Amersham Hybond-C Extra nitrocellulose membrane (GE Life Sciences) and blocked in $5 \%$ skim milk/TBS $(50 \mathrm{mM}$ Tris, $150 \mathrm{mM} \mathrm{NaCl}$, pH 7.5) for $1 \mathrm{~h}$. Washes were with $0.1 \%$ Tween $20 /$ TBS and incubations were RT unless otherwise stated. The membrane was rotated with an anti-PSPC1, anti-SFPQ or anti-NONO mouse mAb ((Kuwahara et al. 2006), 1:1000 in 5\% skim milk/0.1\% Tween20/TBS, O/N, $4^{\circ} \mathrm{C}$ ), washed, then rabbit anti-mouse IRDye 800 secondary antibody (1:10000, Rockland Immunochemicals, 610431020, distributed by Jomar Life Research, Scoresby, Australia; in 5\% skim milk/0.1\% Tween-20/0.01\% SDS/TBS) applied ( $1 \mathrm{~h}$ ) and detected using the Odyssey Imaging System (LI-COR Biosciences, Lincoln, USA).

\section{Results}

\section{PSPC1 is developmentally regulated in germ and Sertoli cells throughout testis development}

Immunohistochemistry was performed to determine the cellular pattern of PSPC1 localisation in the foetal, juvenile and adult mouse testis, building on previous data (Myojin et al. 2004, Major et al. 2015). The foetal ovary was examined to determine if expression of PSPC1 in foetal germ cells was male specific or present in both sexes, as we had previously identified it in male germ cells (Major et al. 2015). Using the previously employed monoclonal antibody, PSPC1 protein was readily detectable in germ cell nuclei in both foetal testis and ovary at E12.5, E14.5 and E16.5 (Fig. 2), with no signal observed in any somatic cell or in the absence of primary antibody in either the ovary (Fig. 2A) or testis (Fig. 2B). In the newborn testis, at 0 days postpartum (dpp), PSPC1 was readily detectable in gonocyte nuclei, but absent from Sertoli cells (Fig. 3A). PSPC1 remained absent from Sertoli cells at $6 \mathrm{dpp}$ and $10 \mathrm{dpp}$, but was observed in nuclei or spermatogonia as well as in the emerging spermatocyte population. PSPC1 was detected in nuclei of spermatogonia, spermatocytes and Sertoli cells at $15 \mathrm{dpp}$. At $26 \mathrm{dpp}$, PSPC1 protein was not detected in spermatogonia, but instead present in pachytene spermatocyte and round spermatid nuclei. The exclusion of PSPC1 from around each XY body in spermatocytes at 15 and $26 \mathrm{dpp}$ appeared as a white space around the blue chromatin body (Fig. 3A: day 15 'zoom'). In adult mouse testis, PSPC1 was detected in spermatocytes, round spermatids and Sertoli cells (Fig. 3B), confirming previous results (Myojin et al. 2004), but again excluded from spermatocyte XY body (Fig. 3B; left 'zoom'). At stage XII, when spermatocytes pass through the second meiotic division, PSPC1 was distributed throughout the cytoplasm (Fig. 3B; right 'zoom'). No cytoplasmic PSPC1 signal was detected in spermatids after the nucleus had reformed. 

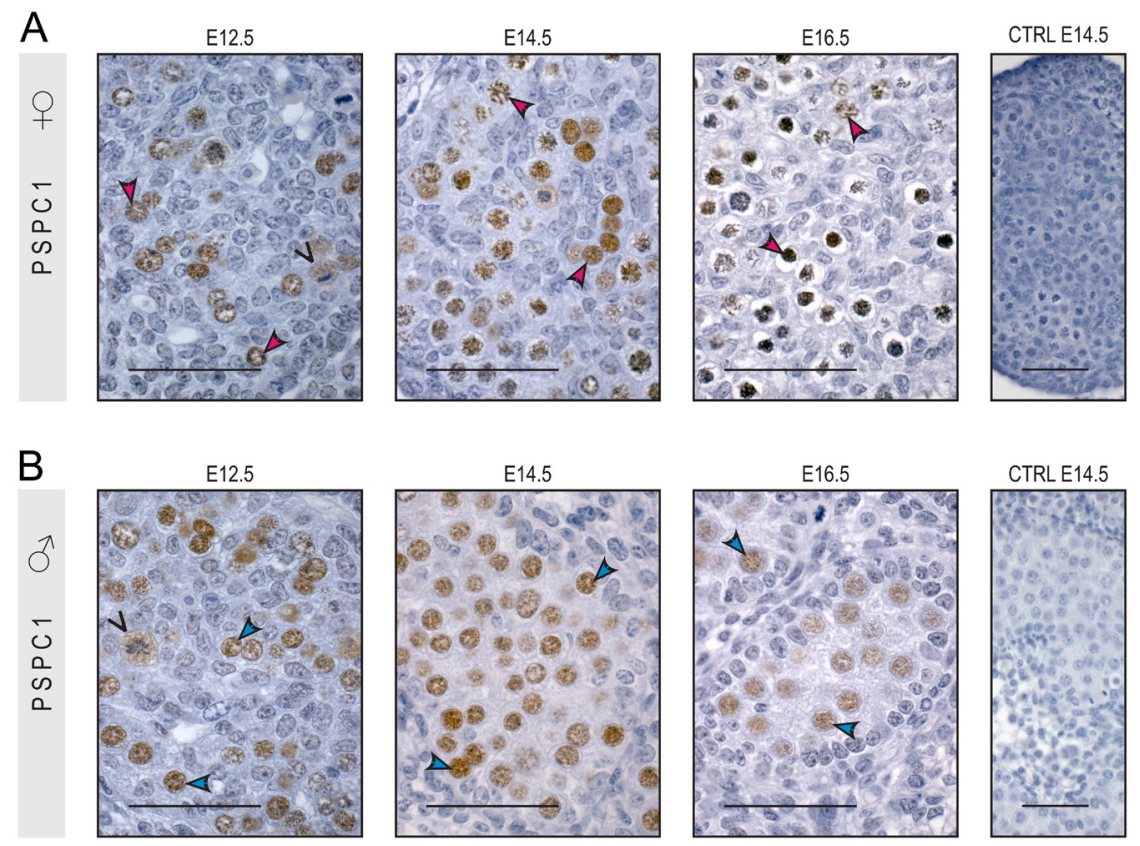

Figure 2 PSPC1 localises to the germ cell nucleus in foetal mouse gonads. PSPC1 immunohistochemistry on E12.5, E14.5 and E16.5 foetal ovary (A: P) and foetal testis (B: $\left.{ }^{\top}\right)$. Control samples lacked primary antibody. Pink and blue arrowheads indicate oogonia in females and gonocytes in males, respectively; $\mathrm{V}$-shape arrowheads point to metaphase cells. Scale bar equals $50 \mu \mathrm{m}$.

\section{Core DBHS paraspeckle components display distinct expression profiles throughout mouse testis development}

The cellular profiles of the two other core DBHS paraspeckle markers, SFPQ and NONO, were also examined during mouse testis development using immunohistochemistry (Fig. 4). NONO was present in the nuclei of Sertoli cells and peritubular myoid cells at each age tested, but absent from germ cells (Fig. 4B). In contrast, SFPQ localised to spermatogonia at $5 \mathrm{dpp}$ and $15 \mathrm{dpp}$, was absent from early meiotic germ cells, but detectable in pachytene spermatocytes (Fig. 4A). Nuclear SFPQ was observed in adult mouse testis spermatocytes and round spermatids, with no signal in spermatogonia. Similar to PSPC1, SFPQ appears excluded from the spermatocyte $X Y$ body in the adult. Sertoli cells were positive for SFPQ at each age examined. Both NONO and SFPQ proteins always localised to the cell nucleus and, unlike PSPC1, were also present within the nucleus of some Leydig cells, which reside in the interstitial space between the seminiferous tubules. No signal was detected in the absence of primary antibody on control sections (Fig. 4).

\section{The IncRNA transcript NEAT1 appears within nuclear foci in adult testis Leydig cells and in immortalised germ cell lines}

To ascertain if paraspeckles were present in the male germ cell subtypes in which both PSPC1 and SFPQ were detected, we next examined the long noncoding RNA NEAT1, which acts as a scaffold for paraspeckle assembly, using in situ hybridisation. A DIG-labelled riboprobe designed to complement a $328 \mathrm{nt}$ region in the $5^{\prime}$ end of NEAT1 (shared by NEAT1_1 and NEAT1_2 transcripts, see Fig. 1 and Supplementary Table 1, see section on supplementary data given at the end of this article) was used in an attempt to detect both short and long transcripts. Signal representing the IncRNA as an insoluble brown-purple precipitate was observed throughout the section (Fig. 5A), but was markedly strongest in the cytoplasm of spermatogonia and spermatocytes in adult testis. A Northern blot using this probe detected the shorter $3.2 \mathrm{kB}$ NEAT1_1 isoform, but no discrete band was observed for the 20.8 kB NEAT1_2 transcript. The larger NEAT1_2 transcript may not be readily detectable by this probe or did not transfer to the membrane due to its larger mass. While this DIGlabelled ISH probe should pick up both short and long NEAT1 transcripts, our results suggest the DIG-labelled ISH approach was predominantly detecting the short NEAT1_1 transcript. The NEAT1_1 band detected in total testis RNA appears slightly larger than that detected in total RNA extracted from kidney or liver; however, this size offset was also observed with the $18 \mathrm{~S}$ and $28 \mathrm{~S}$ rRNA bands and therefore reflects a difference in the way the samples separated within the gel.

Because NEAT1 was not detected in punctuate nuclear foci as expected for paraspeckles, an additional fluorescent in situ hybridisation (FISH) for NEAT1 detection was performed. This employed a commercial FISH probe known to detect punctuate NEAT1 nuclear foci and targeted at the $5^{\prime}$ segment of mouse NEAT1 that is shared by both the long and short transcripts. When hybridised with adult mouse testis sections, this probe yielded a NEAT1 signal in bright nuclear foci in Leydig cells. However, no signal above background 

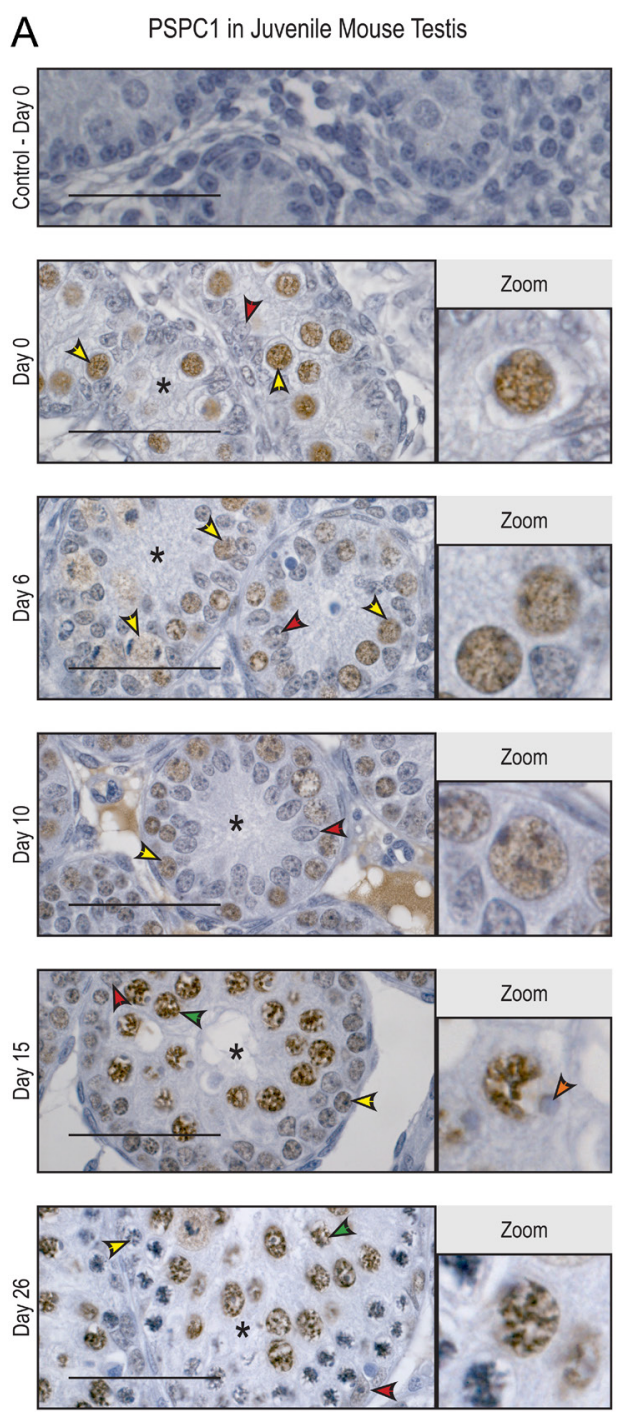

levels appeared within either germ or Sertoli cells in the seminiferous tubules (Fig. 6A). In additional hybridisations examining an embryonic and postnatal testis age series, no other cell types exhibiting punctuate nuclear NEAT1 signal characteristic of paraspeckles were noted (data not shown). We also performed the same FISH method in tandem on GC-1 (Hofmann et al. 1992) and GC-2 (Hofmann et al. 1994, 1995) immortalised cell lines of germ cell origin. The presence of NEAT1 nuclear foci was confirmed within both GC- 1 and GC-2 cells, suggesting both have paraspeckles (Fig. 6B). While both the ISH and FISH probes and their respective detection methods should pick up both NEAT1 transcripts our results suggest, that in our experiments, the DIGlabelled ISH approach was predominantly detecting the short NEAT1_1 transcript, while the FISH method was predominantly detecting the long NEAT1_2 transcript.

Western blots confirmed that all antibodies used to detect core DBHS paraspeckle proteins produced a single specific band of approximately the expected size
Figure 3 PSPC1 localises to the nucleus of germ and Sertoli cells in the postnatal mouse testis. Immunohistochemical localisation of PSPC1 in juvenile and in adult mouse testes. Control samples lacked primary antibody and are negative for signal. Yellow arrowheads: spermatogonia; green arrowheads: spermatocytes; dark blue arrowheads: round spermatids; red arrowheads: Sertoli cell nuclei; black asterisk: Sertoli cell cytoplasm; orange arrowheads: XY body; V-shape arrowhead: metaphase spermatocytes. (A) PSPC1 localisation during the first wave of spermatogenesis at ages indicated. (B) PSPC1 in the adult mouse testis. Scale bar equals $50 \mu \mathrm{m}$. across lysates from adult mouse testis and GC-1/GC-2 cell lines (Fig. 6C). The detected band for NONO in the adult mouse testis is quite faint, in agreement with the observation that NONO is expressed within a smaller proportion of cells within the testis than PSPC1 and SFPQ (Sertoli cells only; Fig. 4). These blots demonstrate the specificity of the antibodies on adult mouse testis and validate the immunohistochemistry results (Figs 2, 3 and 4). These blots also show that in addition to NEAT1, both GC-1 and GC-2 cell lines express all three core DBHS paraspeckle proteins examined.

\section{PSPC1 and $\gamma-H 2 A X$ have reciprocal expression profiles in spermatogenic cells}

PSPC1, SFPQ and NONO have all been implicated in DNA double-strand break repair (Bladen et al. 2005, Li et al. 2009, 2014, Ha et al. 2011, Rajesh et al. 2011, Gao et al. 2014, Yarosh et al. 2015). Mouse embryonic fibroblasts (MEFs) from NONO-deficient mice 
A

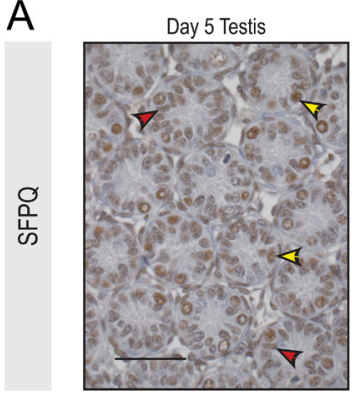

B

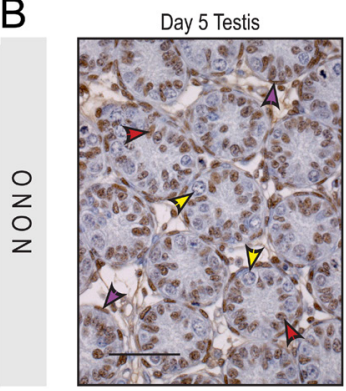

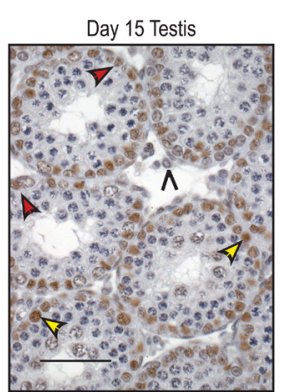

Day 15 Testis

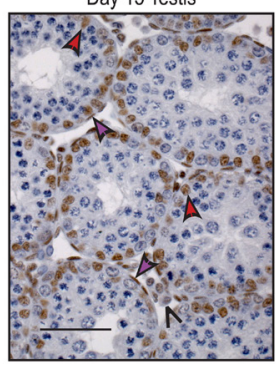

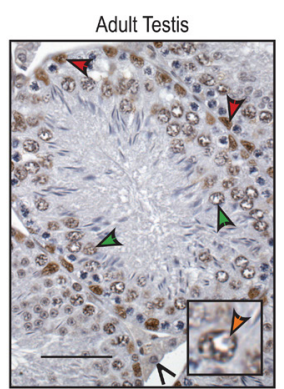
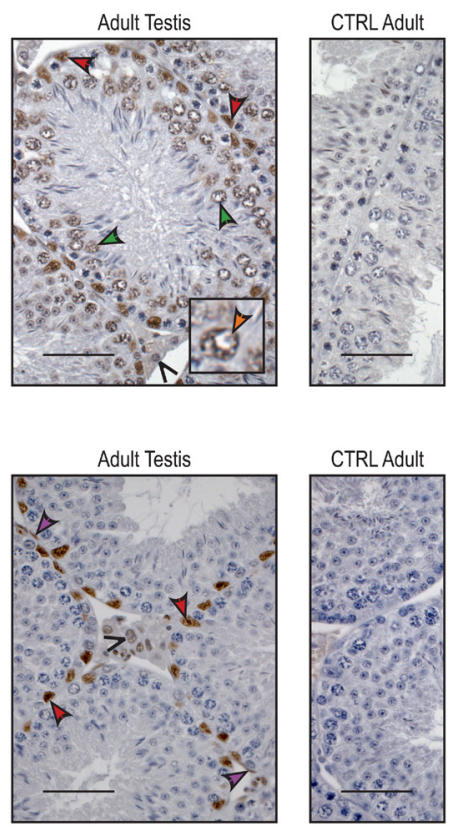

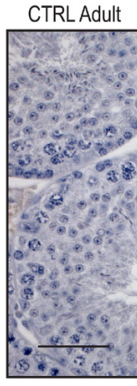

Figure 4 SFPQ and NONO localisation differ in the mouse testis throughout development. Immunohistochemistry localisation using monoclonal antibodies for SFPQ and NONO; control (CTRL) samples lacked primary antibody. Yellow arrowheads: spermatogonia; green arrowheads: spermatocytes; dark blue arrowheads: round spermatids; red arrowheads: Sertoli cell nuclei; orange arrowheads: XY body; purple arrowheads: peritubular myoid cells; $\mathrm{V}$-shape arrowheads: Leydig cells. (A) SFPQ expression at ages indicated. Scale bar equals $50 \mu \mathrm{m}$. (B) NONO expression at ages indicated. upregulate PSPC1 expression to compensate for the absence of NONO (Li et al. 2014), and when NONO levels are reduced by siRNA knockdown, SFPQ can form a stable complex with PSPC1 that also localises to DNA damage sites (Ha et al. 2011). We hypothesised that since NONO was not detected in spermatogenic cells at any age, the germ cells expressing SFPQ and PSPC1, such as spermatocytes and round spermatids of the adult mouse testis, may have unique mechanisms for managing DNA double-strand breaks. Phosphorylation of histone $\mathrm{H} 2 \mathrm{AX}$ at serine 139 to form $\gamma-\mathrm{H} 2 \mathrm{AX}$ is widely considered a reliable marker of double-strand breaks (Rogakou et al. 1998). Many double-strand breaks are induced and then repaired as part of meiosis and chromatin remodelling during spermatogenesis. The $\gamma-\mathrm{H} 2 \mathrm{AX}$ pattern has been well documented in the testis (Hamer et al. 2003), and we noted that PSPC1 and SFPQ are detected in a cohort of cells/subcellular sites that are mutually exclusive from $\gamma-\mathrm{H} 2 \mathrm{AX}$ during spermatogenesis. These reciprocal staining profiles are readily visualised through co-immunofluorescence for PSPC1 and $\gamma-\mathrm{H} 2 \mathrm{AX}$ on adult mouse testis sections (Fig. 7). The $\gamma-\mathrm{H} 2 \mathrm{AX}$ signal is present in the spermatocyte XY body, while PSPC1 is excluded from the XY body but visible across the rest of the nuclear compartment. This result suggests that PSPC1 and SFPQ may direct repair of double-strand breaks where they are present, at cellular sites that are complementary to $\gamma-\mathrm{H} 2 \mathrm{AX}$.
A ISH for NEAT1 IncRNA in Adult Mouse Testis Sections

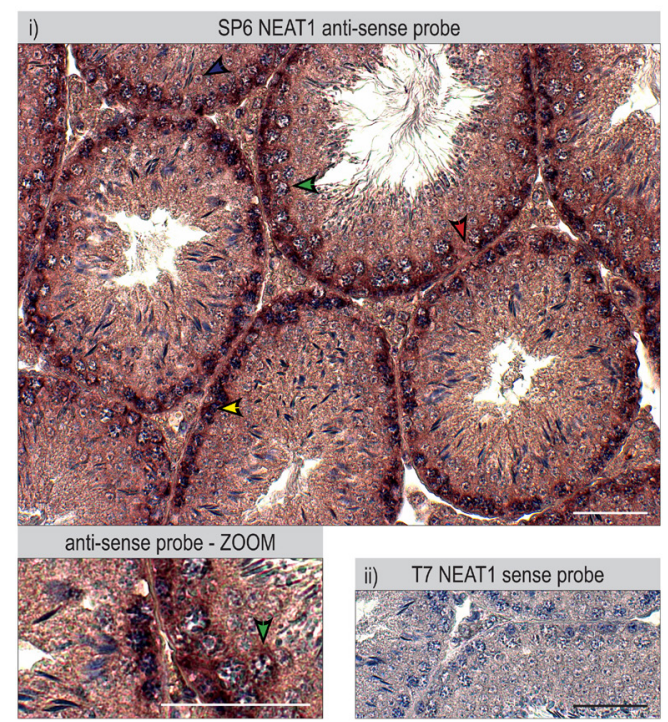

B NEAT1 IncRNA Northern Blot

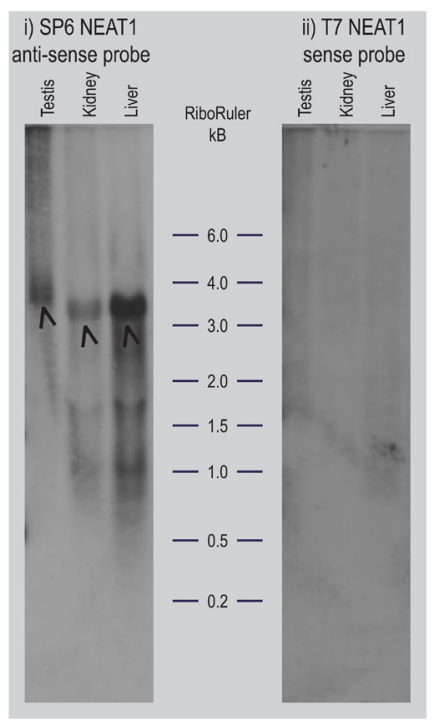

Figure 5 NEAT1 IncRNA in situ hybridisation with adult mouse testis sections and NEAT1 Northern Blot. (A) Localisation of NEAT1 transcript in the adult mouse testis using an anti-sense probe (i) and a control sense probe (ii). Yellow arrowheads: spermatogonia; green arrowheads: spermatocytes; dark blue arrowheads: round spermatids; red arrowheads: Sertoli cell nuclei. (B) NEAT1 Northern Blots on total RNA from extracted from testis, kidney and liver ( $30 \mu \mathrm{g}$ per lane). Bands of the expected size for the shorter NEAT1_1 transcript (3.2 kB) are observed in total RNA from all samples (V-shape arrowhead) using the anti-sense probe (i) and are absent from the control sense probe (ii) blot. Size standards in kilobases $(\mathrm{kB})$ indicate the RNA ladder sizes. Scale bar equals $50 \mu \mathrm{m}$. 
A FISH/IF for NEAT1 Transcript and PSPC1 Protein in Adult Mouse Testis Tissue Sections
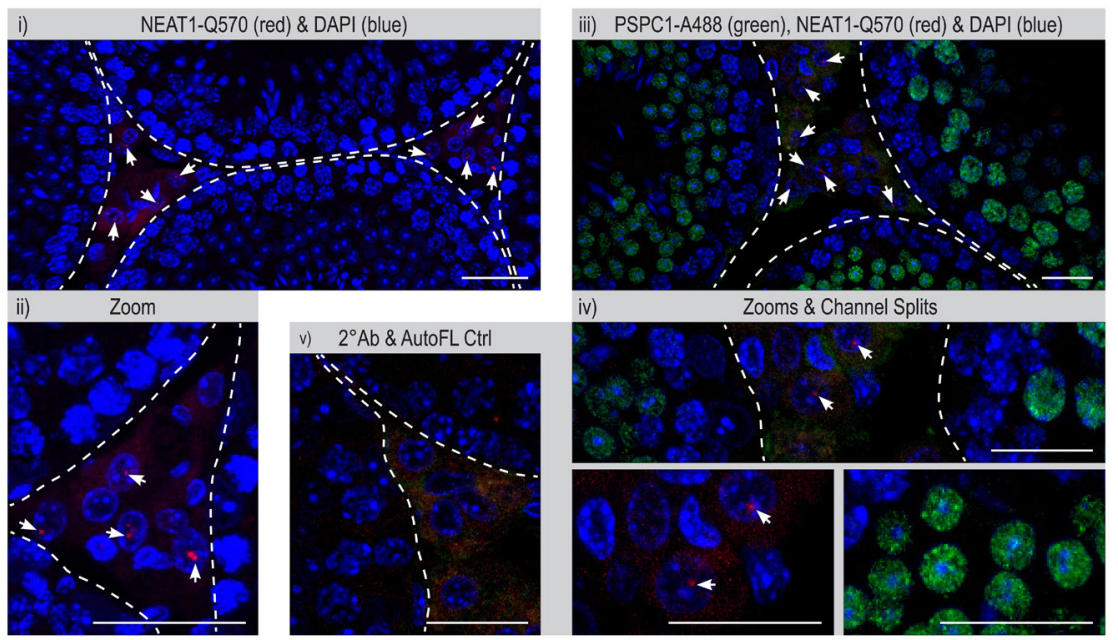

B
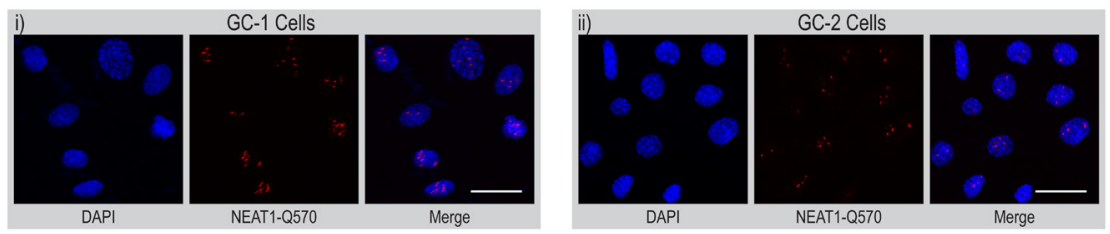

C Antibody Validations for PSPC1, SFPQ and NONO with Adult Mouse Testis (AdMT), GC-1 and GC-2
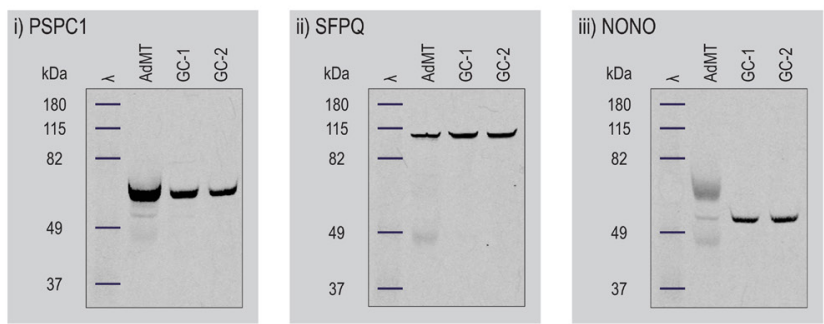

\section{Expression of other paraspeckle proteins throughout spermatogenesis}

That NEAT1 transcripts in nuclear foci, most likely corresponding to paraspeckles, were observed in interstitial Leydig cells, but not in any germ cells was somewhat surprising given that strong PSPC1 signals are found throughout the nucleoplasm and in addition, bright PSPC1 nuclear foci are often observed (Fig. 6Aiiiiv (green foci), Fig. 7, Major et al. 2015 and unpublished). Furthermore, the comparative expression levels of the long PSPC1 isoform protein (Fig. 1) have been shown to be many fold higher in the testis than in any other tissue examined (Myojin et al. 2004). Recent findings have demonstrated that many paraspeckle proteins (including PSPC1) contain prion-like domains that can facilitate the formation of hydrogels and through liquid-phase transitions are thought to contribute to paraspeckle formation (Hennig et al. 2015, Fox et al. 2018, Yamazaki et al. 2018). Of the seven paraspeckle proteins deemed

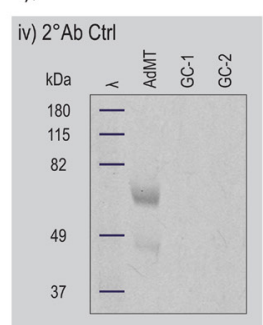

Figure 6 Paraspeckles in the adult mouse testis and in GC-1 and GC-2 germ cell-derived cell lines. Confocal Z-series images, visualised as maximum intensity projections, all have DAPI included as a nuclear marker and $20 \mu \mathrm{m}$ scale bars (A and B). (A) FISH (i-ii) or sequential FISH/IF (iii-v) on adult mouse testis sections using Stellaris RNA FISH probes for NEAT1 labelled with Quasar 570 (Q570) dye. Sequential FISH/IF samples also had a PSPC1 antibody and an Alexa Fluor 488 (A488) secondary antibody applied. Dashed lines indicate the borders of adjacent seminiferous tubules, with NEAT1 signal seen as punctuate nuclear foci within the Leydig cells of the interstitial compartment between tubules. Some non-specific signal was observed, particularly within the cytoplasm of the interstitial cells, in the A488 secondary antibody only and autofluorescence control sample ( $2^{\circ} \mathrm{Ab}$ and AutoFL Ctrl; v). (B) FISH performed on GC-1 and GC-2 cell lines using Stellaris RNA FISH NEAT1 probes labelled with Quasar 570 (Q570) dye displayed punctuate nuclear NEAT1 foci, marking paraspeckles throughout the nucleus of most cells. (C) Western blots including a prestained protein ladder $(\lambda)$ to indicate the approximate molecular weights in kilodaltons (kDa). Single bands of the correct approximate molecular weight were observed for PSPC1 (i), SFPQ (ii) and $\mathrm{NONO}$ (iii) using adult mouse testis

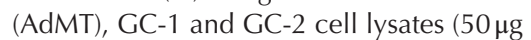
total protein per lane). The NONO band within the AdMT lysate was very faint, but comparison with the membrane incubated with secondary antibody alone ( $2^{\circ} \mathrm{Ab} \mathrm{Ctrl}$; iv), demonstrates a specific and clear signal for NONO in the AdMT.

to be essential to paraspeckle formation by siRNA knockdown (Naganuma et al. 2012, Hennig et al. 2015), transcripts encoding all (SFPQ, RBM14, DAZAP1, FUS, HNRNPK and HNRNPH3) except NONO have been identified in spermatocytes. This can be seen in publicly accessible microarray data (GeoProfiles; Shima et al. 2004, Namekawa et al. 2006, Barrett et al. 2013), with transcripts encoding many of these proteins showing peaks of expression at this stage of testis development (Fig. 8). With the exception of HNRNPK and HNRNPH3, all of these proteins have been identified to contain prion-like domains (Hennig et al. 2015). Overexpression of the RBM14 prion-like domain in HeLa cells can promote aggregation independent of paraspeckles (Hennig et al. 2015). Based on these observations, we speculate that in germ cells containing high levels of PSPC1, but undetectable NEAT1_2, the prion-like domains in PSPC1 (and potentially others such as SFPQ, RBM14, DAZAP1 and FUS) could facilitate nucleation of unique testis-specific paraspeckle-like nuclear 
PSPC1 and $y-H 2 A X$ are present in mutually exclusive cellular/subcellular localisations
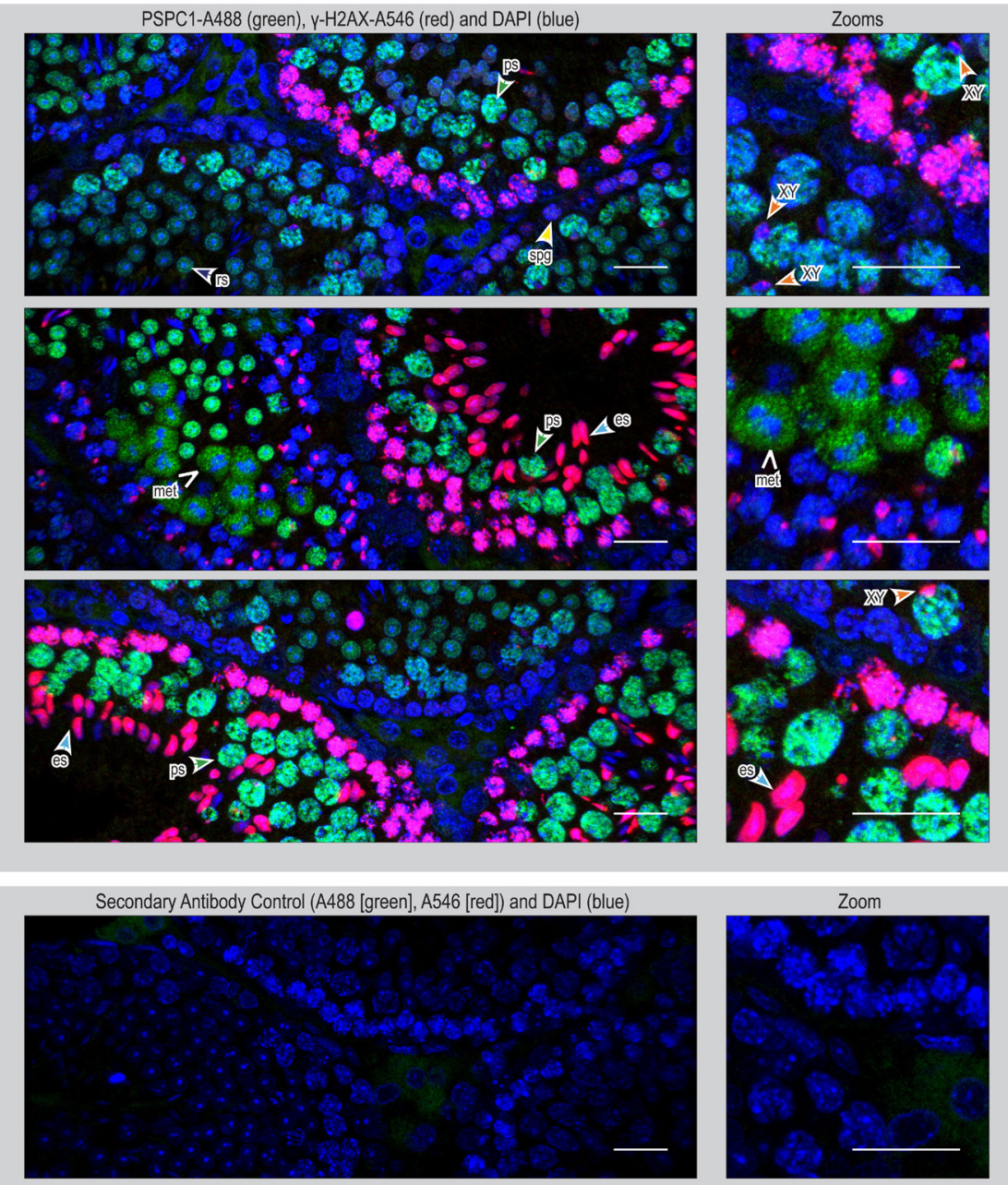

Figure 7 PSPC1 and $\gamma-\mathrm{H} 2 \mathrm{AX}$ expression in the adult mouse testis. Confocal Z-series images, visualised as maximum intensity projections, all have DAPI included as a nuclear marker and $20 \mu \mathrm{m}$ scale bars. Samples had anti-PSPC1 antibody with an Alexa Fluor 488 (A488) secondary and an anti- $\gamma-\mathrm{H} 2 \mathrm{AX}$ antibody with an Alexa Fluor 546 (A546) secondary applied. The secondary antibody control had no primary antibodies applied and lacks green or red signals. yellow arrowheads (spg): spermatogonia; green arrowheads (ps): pachytene spermatocytes; dark blue arrowheads ( $\mathrm{rs}$ ): round spermatids; light blue arrowheads (es): elongating spermatids; orange arrowheads $(\mathrm{XY})$ : $\mathrm{XY}$ body; $\mathrm{V}$-shape arrowhead (met): metaphase spermatocytes. structures or functional aggregates. This would explain the presence of PSPC1 punctuate nuclear foci observed in spermatocytes and spermatids. These structures may contain NEAT1_1 transcripts or rely on other RNA transcript(s) for assembly or stabilisation.

\section{Discussion}

This study extends previous reports of PSPC1 and paraspeckle proteins (Myojin et al. 2004, Kuwahara et al. 2006) to describe their localisation throughout gonadal development. Comparison of PSPC1, SFPQ, NONO and NEAT1 localisation data (summarised in Fig. 9) demonstrates that not all paraspeckle constituents are expressed in the same testicular cell types. NONO localised specifically to Sertoli and peritubular myoid cells and was undetectable in germ cells at any age, unlike PSPC1 and SFPQ, which were present in germ cells throughout testis development. In addition, SFPQ was present in Sertoli cells of the neonatal testis, whereas PSPC1 is detectable in these cells only from $15 \mathrm{dpp}$ onwards. Collectively, these data suggest that testicular cells have distinct requirements for different paraspeckle constituents and further analysis of the discrete roles of these proteins in the testis is required.

The immunohistochemistry data are consistent with dynamic roles for PSPC1 in both germ and Sertoli cells. The onset of PSPC1 expression in Sertoli cells as they become terminally differentiated matches the known transition of Sertoli cells to an androgen-responsive state (Buzek \& Sanborn 1988, Zhou et al. 1996, Smith et al. 2015). Nuclear-localised PSPC1 in the foetal testis and ovary indicates a broad requirement for this protein in germ cells in the embryo. PSPC1 has been shown to regulate transcription from the androgen receptor promoter (Kuwahara et al. 2006), a critical control gene in Sertoli cell biology, and the longer isoform of PSPC1 is enriched in the testis (Myojin et al. 2004). The presence of PSPC1 in gonocytes therefore suggests it may influence androgen action in these cells (Merlet et al. 2007), as described in adult Sertoli cells (Kuwahara et al. 2006). In the early postnatal testis a function in 
A
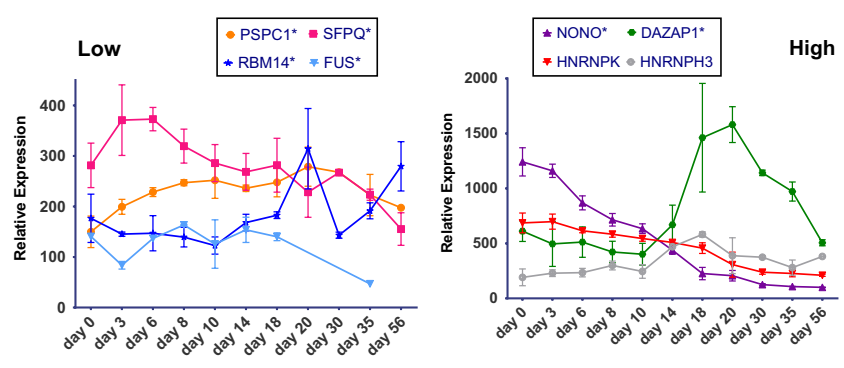

B
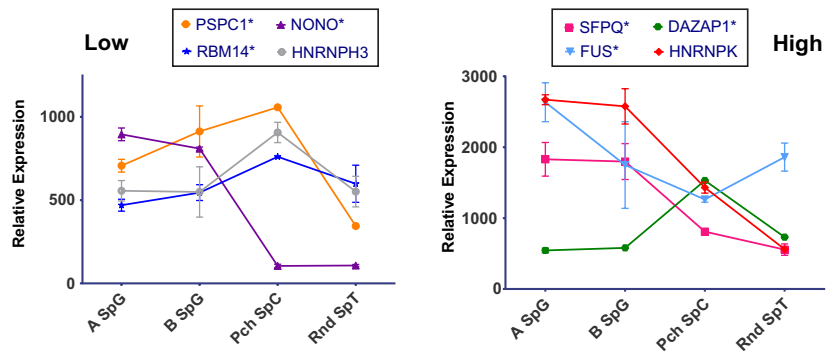

Figure 8 Expression profiles of paraspeckle proteins shown to be essential to paraspeckle formation by siRNA knockdown. Single probesets representing each gene were selected from each GEO dataset in a systematic manner as previously described (Major et al. 2011). Data are separated into lower/higher detection levels for visualisation and error bars correspond to standard error of the mean (SEM), where multiple values were present. Proteins containing known prion-like domains (Hennig et al. 2015) are indicated with an asterisks $(*)$. (A) Mouse testis age series are from the GEO datasets GDS605, GDS606 and GDS607 (Shima et al. 2004), where progressively differentiated germ cells appear, concurrent with the first wave of spermatogenesis. Probesets shown here are as follows: PSPC1 (Pspc1 GDS605 103393_at), SFPQ (Sfpq GDS605 99621_s_ at), NONO (Nono GDS605 93830_at), RBM14 (Rbm14 GDS605 100138_f_at), DAZAP1 (Dazap1 GDS606 109765_f_at), FUS (Fus GDS606 107506_at), HNRNPK (Hnrnpk GDS605 94041_at) and HNRNPH3 (Hnrnph3 GDS605 104231_at). (B) Isolated mouse germ cell types from GEO dataset GDS2390, containing Type A spermatogonia (A SpG), Type B spermatogonia (B SpG), pachytene spermatocytes (Pch Spc) and round spermatids (Rnd SpT) (Namekawa et al. 2006). Probesets shown here are as follows: PSPC1 (Pspc1 1423192_at), NONO (Nono 1448103_s_at), SFPQ (Sfpq 1423795 at), RBM14 (Rbm14 1436979_x_at), DAZAP1 (Dazap1 1419275_at), FUS (Fus 1451285_at), HNRNPK (Hnrnpk 1460547_a_at) and HNRNPH3 (Hnrnph3 1455491_at).

spermatogonial maturation is implied, as expression is seen solely in spermatogonia. A switch is evident by 26 dpp however, with PSPC1 now absent from mitotic germ cells, but present only in meiotic and haploid germ cells. Hence, in the developing testis, PSPC1 appears to be present as each germ cell subtype first appears. An interesting observation given PSPC1 has reported roles in the maintenance of stemness, metastasis and EMT through TGF- $\beta 1$ signalling and Smad2/3 target switching (Salvador \& Gomis 2018, Yeh et al. 2018).

PSPC1 and SFPQ proteins are excluded from the transcriptionally inactive $\mathrm{XY}$ body of spermatocytes (Turner et al. 2004, 2006). PSPC1 is cytosolic during metaphase/anaphase of meiosis, when no nuclear envelope is present, and this is closely followed by its translocation into the round spermatid nucleus. We interpret this as indicating PSPC1 is stable in the cytosol until the nuclear envelope reforms and then it is transported into the nucleus by IMP $\alpha 2$, which is abundant at this stage (Major et al. 2015, 2017). PSPC1 and SFPQ are detected in a cohort of spermatogenic cells and subcellular sites that are distinct from $\gamma-\mathrm{H} 2 \mathrm{AX}$. PSPC1 has also been implicated in the DNA doublestrand break repair response through regulation of the G1/S checkpoint, when it is proposed to halt the cell cycle to allow DNA repair (Gao et al. 2014), we postulate it could perform similar roles during meiotic divisions.

Two independent in situ hybridisation methods used to detect the NEAT1 IncRNAs were conducted with probes that should detect both NEAT1_1 and NEAT1_2 transcripts. However, the outcomes indicate that each method preferentially detected one of these isoforms. The fluorescence-based detection method revealed NEAT1 in punctate nuclear foci in Leydig cells and in the GC-1 and GC-2 cell lines (Fig. 6), suggesting this method and these conditions facilitated detection of the longer NEAT1_2 transcript that mediates paraspeckle nucleation. In contrast, the conventional ISH method, which relies on enzymatic production of an insoluble brown-purple precipitate, appeared to favour detection of NEAT1_1; a relatively weak signal was observed throughout the adult testis, and a distinct, stronger signal was visible in the cytoplasm of spermatogonia and spermatocytes (Fig. 5A). In agreement with this, a Northern blot using this probe detected only the shorter $3.2 \mathrm{~kb}$ mouse NEAT1_1 transcript (Fig. 5B). The NEAT1_1 transcript has been reported to act as a transcriptional regulator by promoting active chromatin states of specific promoters (Chakravarty et al. 2014, Li et al. 2017). While signal was not excluded from the nucleus, suggesting NEAT1 could be acting as a transcriptional regulator in these cells, the signal was greatest within the cytoplasm. SFPQ and NONO have been reported as components of a cytoplasmic RNA-transporting granule in dendrites (Kanai et al. 2004), but no cytoplasmic functions for NEAT1 have as yet been reported. The functional significance of cytoplasmic NEAT1 signal within male germ cells warrants further investigation.

Our observations of NEAT1 variant expression align with a report that the longer NEAT1_2 transcript is restricted to the hormone-producing Leydig and corpus luteal cells in the testes and ovaries respectively (Nakagawa \& Hirose 2012), while the NEAT1_1 transcript is less restricted (Nakagawa et al. 2011 - Supplementary Fig. 1) Almost half of female NEAT1 ${ }^{-1-}$ mice, which lack paraspeckles, fail to become pregnant due to severely impaired luteal tissue formation, which can be rescued by progesterone administration (Nakagawa et al. 2014). No phenotype for NEAT1 ${ }^{-/-}$male mice has been reported yet, but it would be interesting to determine if these 


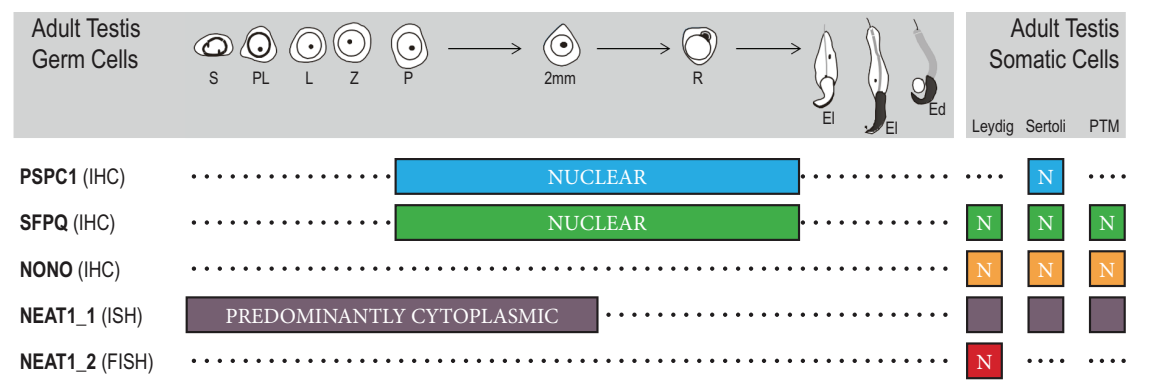

Figure 9 Summary of core paraspeckle component expression in the mouse testis. Expression profiles determined for paraspeckle components throughout testis development using immunohistochemistry (IHC), in situ hybridisation (ISH) or fluorescent in situ hybridisation (FISH), dashed lines indicates cells lacking detectable signal. Germ cells are shown at increasingly differentiated stages of development: spermatogonia (S), preleptotene spermatocytes $(\mathrm{PL})$, zygotene spermatocytes $(Z)$, pachytene spermatocytes $(P)$, second meiotic metaphase $(2 \mathrm{~mm})$, round spermatids $(\mathrm{R})$, elongating spermatids (EI) and elongated spermatids (Ed). Somatic Cell types shown are Leydig, Sertoli and Peritubular Myoid (PTM) cells with nuclear $(\mathrm{N})$ localisation indicated. mice have reduced Leydig cell numbers or impaired Leydig cell function, potentially impacting androgen production and thereby masculinisation or reproductive and sexual function. Only $24 \%$ of pups from NEAT1 $1^{-1-}$ mothers survive past 5 days unless placed with a foster mother, reflecting important roles in mammary gland development and function (Standaert et al. 2014). Other paraspeckle-related NEAT1 roles are demonstrated in adipogenesis (Gernapudi et al. 2016) and in muscle differentiation, as myoblasts transition to myotubes (Sunwoo et al. 2009). In tumours, hypoxia-inducible factor HIF- $2 \alpha$ can induce NEAT1 expression and paraspeckle formation, promoting cancer cell survival under hypoxic conditions (Choudhry et al. 2015).

The GC-1 and GC-2 cell lines were derived from testicular germ cells, corresponding to successive stages of germ cell development (GC-1: Hofmann et al. 1992, GC-2: Hofmann et al. 1994, 1995) which lacked NEAT1positive nuclear foci (paraspeckles) and the DBHS protein NONO. Despite this, both GC-1 and GC-2 cells clearly display paraspeckles (NEAT1-positive nuclear foci; Fig. 6B) and express NONO protein (Fig. 6Ciii). The appearance of NEAT1-positive paraspeckles and NONO within both GC-1 and GC-2 cells, while they are absent from their primary cell counterparts, may arise as a consequence of their transition from primary cells to an immortalised cell line with ongoing proliferative and survival behaviour. This is in accord with observations that paraspeckles are ubiquitous across all mammalian cell lines examined to date, except embryonic stem cells (Bond \& Fox 2009, Fox \& Lamond 2010, Nakagawa \& Hirose 2012), while in vivo paraspeckles are restricted to limited populations of cells within tissues (Nakagawa et al. 2011).

This study has carefully delineated the cellular expression profiles and subcellular localisations of the three core DBHS paraspeckles proteins throughout mouse testis development. Not all DBHS proteins were found in the same testicular cell types at the same developmental time points, suggesting that testicular cells have distinct requirements for the different paraspeckle constituents and further analysis of the discrete roles of these in the testis is required. The IncRNA NEAT1 which acts as a structural scaffold for paraspeckles was detected throughout the testis, but evidence that long and short transcript variants are differentially expressed was provided. The potential for paraspeckle proteins to contribute to maintenance of genetic integrity in the germline was highlighted from the reciprocal expression profiles of $\gamma-\mathrm{H} 2 \mathrm{AX}$ and PSPC1/SFPQ. These data provide a foundation for future studies to consider which amongst the plethora of diverse nuclear functions that DBHS proteins are being discovered to perform are relevant to spermatogenesis.

\section{Supplementary data}

This is linked to the online version of the paper at https://doi.org/10.1530/REP-19-0139.

\section{Declaration of interest}

The authors declare that there is no conflict of interest that could be perceived as prejudicing the impartiality of the research reported.

\section{Funding}

This work was supported in part by grants from the Australian Research Council Centre of Excellence in Biotechnology and Development (COE348239 to K L and D J), an Australian Postgraduate Award (A M) and the National Health and Medical Research Council of Australia (K L, ID1079646; D J, ID384105/APP1002486).

\section{Author contribution statement}

$A M, C H, K L$ and $D$ J designed the experiments and analyses. $\mathrm{A} \mathrm{M}$ and $\mathrm{CH}$ implemented the experiments and analyses, with support from J Y. A M, C H and K L were primarily responsible 
for writing the manuscript, with all authors making significant contributions to the final manuscript.

\section{Acknowledgements}

The authors acknowledge the support of the Monash Micro Imaging facility (MMI, Monash University, Clayton, Australia) during image acquisition and analysis. They thank Archa Fox and Romaly Butler for their helpful discussions.

\section{References}

Barrett T, Wilhite SE, Ledoux P, Evangelista C, Kim IF, Tomashevsky M, Marshall KA, Phillippy KH, Sherman PM, Holko M et al. 2013 NCBI GEO: archive for functional genomics data sets - update. Nucleic Acids Research 41 D991-D995. (https://doi.org/10.1093/nar/gks1193)

Bladen CL, Udayakumar D, Takeda Y \& Dynan WS 2005 Identification of the polypyrimidine tract binding protein-associated splicing factor. p54(nrb) complex as a candidate DNA double-strand break rejoining factor. Journal of Biological Chemistry 280 5205-5210. (https://doi. org/10.1074/jbc.M412758200)

Blume CJ, Hotz-Wagenblatt A, Hullein J, Sellner L, Jethwa A, Stolz T, Slabicki M, Lee K, Sharathchandra A, Benner A et al. 2015 p53dependent non-coding RNA networks in chronic lymphocytic leukemia. Leukemia 29 2015-2023. (https://doi.org/10.1038/leu.2015.119)

Bond CS \& Fox AH 2009 Paraspeckles: nuclear bodies built on long noncoding RNA. Journal of Cell Biology 186 637-644. (https://doi. org/10.1083/jcb.200906113)

Brown SA, Ripperger J, Kadener S, Fleury-Olela F, Vilbois F, Rosbash M \& Schibler U 2005 PERIOD1-associated proteins modulate the negative limb of the mammalian circadian oscillator. Science 308 693-696. (https://doi.org/10.1126/science.1107373)

Brown JA, Valenstein ML, Yario TA, Tycowski KT \& Steitz JA 2012 Formation of triple-helical structures by the 3'-end sequences of MALAT1 and MENbeta noncoding RNAs. PNAS 109 19202-19207. (https://doi. org/10.1073/pnas.1217338109)

Buzek SW \& Sanborn BM 1988 Increase in testicular androgen receptor during sexual maturation in the rat. Biology of Reproduction 39 39-49. (https://doi.org/10.1095/biolreprod39.1.39)

Byskov AG 1986 Differentiation of mammalian embryonic gonad. Physiological Reviews 66 71-117. (https://doi.org/10.1152/ physrev.1986.66.1.71)

Chakravarty D, Sboner A, Nair SS, Giannopoulou E, Li R, Hennig S, Mosquera JM, Pauwels J, Park K, Kossai M et al. 2014 The oestrogen receptor alpha-regulated IncRNA NEAT1 is a critical modulator of prostate cancer. Nature Communications 5 5383. (https://doi. org/10.1038/ncomms6383)

Chen LL \& Carmichael GG 2009 Altered nuclear retention of mRNAs containing inverted repeats in human embryonic stem cells: functional role of a nuclear noncoding RNA. Molecular Cell 35 467-478. (https:// doi.org/10.1016/j.molcel.2009.06.027)

Choudhry H, Albukhari A, Morotti M, Haider S, Moralli D, Smythies J, Schodel J, Green CM, Camps C, Buffa F et al. 2015 Tumor hypoxia induces nuclear paraspeckle formation through HIF-2alpha dependent transcriptional activation of NEAT1 leading to cancer cell survival. Oncogene 34 4546. (https://doi.org/10.1038/onc.2014.431)

Clemson CM, Hutchinson JN, Sara SA, Ensminger AW, Fox AH, Chess A \& Lawrence JB 2009 An architectural role for a nuclear noncoding RNA: NEAT1 RNA is essential for the structure of paraspeckles. Molecular Cell 33 717-726. (https://doi.org/10.1016/j.molcel.2009.01.026)

Fong KW, Li Y, Wang W, Ma W, Li K, Qi RZ, Liu D, Songyang Z \& Chen J 2013 Whole-genome screening identifies proteins localized to distinct nuclear bodies. Journal of Cell Biology 203 149-164. (https://doi. org/10.1083/jcb.201303145)

Fox AH \& Lamond AI 2010 Paraspeckles. Cold Spring Harbor Perspectives in Biology 2 a000687. (https://doi.org/10.1101/cshperspect.a000687)

Fox AH, Lam YW, Leung AK, Lyon CE, Andersen J, Mann M \& Lamond AI 2002 Paraspeckles: a novel nuclear domain. Current Biology 12 13-25. (https://doi.org/10.1016/S0960-9822(01)00632-7)
Fox AH, Bond CS \& Lamond Al 2005 P54nrb forms a heterodimer with PSP1 that localizes to paraspeckles in an RNA-dependent manner. Molecular Biology of the Cell 16 5304-5315. (https://doi.org/10.1091/ mbc.e05-06-0587)

Fox AH, Nakagawa S, Hirose T \& Bond CS 2018 Paraspeckles: where long noncoding RNA meets phase separation. Trends in Biochemical Sciences 43 124-135. (https://doi.org/10.1016/j.tibs.2017.12.001)

Gao X, Kong L, Lu X, Zhang G, Chi L, Jiang Y, Wu Y, Yan C, DuerksenHughes P, Zhu X et al. 2014 Paraspeckle protein 1 (PSPC1) is involved in the cisplatin induced DNA damage response - role in G1/S checkpoint. PLoS ONE 9 e97174. (https://doi.org/10.1371/journal.pone.0097174)

Gernapudi R, Wolfson B, Zhang Y, Yao Y, Yang P, Asahara H \& Zhou Q 2016 MicroRNA 140 promotes expression of long noncoding RNA NEAT1 in adipogenesis. Molecular and Cellular Biology 36 30-38. (https://doi.org/10.1128/MCB.00702-15)

Gozani O, Patton JG \& Reed R 1994 A novel set of spliceosome-associated proteins and the essential splicing factor PSF bind stably to pre-mRNA prior to catalytic step II of the splicing reaction. EMBO Journal 13 3356-3367. (https://doi.org/10.1002/j.1460-2075.1994.tb06638.x)

Guo S, Chen W, Luo Y, Ren F, Zhong T, Rong M, Dang Y, Feng Z \& Chen G 2015 Clinical implication of long non-coding RNA NEAT1 expression in hepatocellular carcinoma patients. International Journal of Clinical and Experimental Pathology 8 5395-5402.

Ha K, Takeda Y \& Dynan WS 2011 Sequences in PSF/SFPQ mediate radioresistance and recruitment of PSF/SFPQ-containing complexes to DNA damage sites in human cells. DNA Repair 10 252-259. (https://doi. org/10.1016/j.dnarep.2010.11.009)

Hamer G, Roepers-Gajadien HL, van Duyn-Goedhart A, Gademan IS, Kal HB, van Buul PP \& de Rooij DG 2003 DNA double-strand breaks and gamma-H2AX signaling in the testis. Biology of Reproduction $\mathbf{6 8}$ 628-634. (https://doi.org/10.1095/biolreprod.102.008672)

He C, Jiang B, Ma J \& Li Q 2016 Aberrant NEAT1 expression is associated with clinical outcome in high grade glioma patients. APMIS 124 169-174. (https://doi.org/10.1111/apm.12480)

Hennig S, Kong G, Mannen T, Sadowska A, Kobelke S, Blythe A, Knott GJ, lyer KS, Ho D, Newcombe EA et al. 2015 Prion-like domains in RNA binding proteins are essential for building subnuclear paraspeckles. Journal of Cell Biology 210 529-539. (https://doi.org/10.1083/jcb.201504117)

Hirose T, Virnicchi G, Tanigawa A, Naganuma T, Li R, Kimura H, Yokoi T, Nakagawa S, Benard M, Fox AH et al. 2014 NEAT1 long noncoding RNA regulates transcription via protein sequestration within subnuclear bodies. Molecular Biology of the Cell 25 169-183. (https://doi. org/10.1091/mbc.E13-09-0558)

Hofmann MC, Abramian D \& Millan JL 1995 A haploid and a diploid cell coexist in an in vitro immortalized spermatogenic cell line. Developmental Genetics 16 119-127. (https://doi.org/10.1002/ dvg.1020160205)

Hofmann MC, Narisawa S, Hess RA \& Millan JL 1992 Immortalization of germ cells and somatic testicular cells using the SV40 large T antigen. Experimental Cell Research 201 417-435. (https://doi.org/10.1016/00144827(92)90291-f)

Hofmann MC, Hess RA, Goldberg E \& Millan JL 1994 Immortalized germ cells undergo meiosis in vitro. PNAS 91 5533-5537. (https://doi. org/10.1073/pnas.91.12.5533)

Hogarth CA, Calanni S, Jans DA \& Loveland KL 2006 Importin alpha mRNAs have distinct expression profiles during spermatogenesis. Developmental Dynamics 235 253-262. (https://doi.org/10.1002/ dvdy.20569)

Hu X, Bao J, Wang Z, Zhang Z, Gu P, Tao F, Cui D \& Jiang W 2016 The plasma IncRNA acting as fingerprint in non-small-cell lung cancer. Tumour Biology 37 3497-3504. (https://doi.org/10.1007/s13277-0154023-9)

Ito $\mathrm{T}$, Watanabe $\mathrm{H}$, Yamamichi $\mathrm{N}$, Kondo $\mathrm{S}$, Tando $\mathrm{T}$, Haraguchi $\mathrm{T}$, Mizutani T, Sakurai K, Fujita S, Izumi T et al. 2008 Brm transactivates the telomerase reverse transcriptase (tert) gene and modulates the splicing patterns of its transcripts in concert with p54(nrb). Biochemical Journal 411 201-209. (https://doi.org/10.1042/BJ20071075)

Izumi H, McCloskey A, Shinmyozu K \& Ohno M 2014 p54nrb/NonO and PSF promote $U$ snRNA nuclear export by accelerating its export complex assembly. Nucleic Acids Research 42 3998-4007. (https://doi. org/10.1093/nar/gkt1365)

Jiang L, Shao C, Wu QJ, Chen G, Zhou J, Yang B, Li H, Gou LT, Zhang Y, Wang $\mathrm{Y}$ et al. 2017 NEAT1 scaffolds RNA-binding proteins and the 
microprocessor to globally enhance pri-miRNA processing. Nature Structural and Molecular Biology 24 816-824. (https://doi.org/10.1038/ nsmb.3455)

Kameoka S, Duque P \& Konarska MM 2004 p54(nrb) associates with the 5' splice site within large transcription/splicing complexes. EMBO Journal 23 1782-1791. (https://doi.org/10.1038/sj.emboj.7600187)

Kanai Y, Dohmae N \& Hirokawa N 2004 Kinesin transports RNA: isolation and characterization of an RNA-transporting granule. Neuron 43 513-525. (https://doi.org/10.1016/j.neuron.2004.07.022)

Kaneko S, Rozenblatt-Rosen O, Meyerson M \& Manley JL 2007 The multifunctional protein p54nrb/PSF recruits the exonuclease XRN2 to facilitate pre-mRNA 3' processing and transcription termination. Genes and Development 21 1779-1789. (https://doi.org/10.1101/gad.1565207)

Kowalska E, Ripperger JA, Muheim C, Maier B, Kurihara Y, Fox AH, Kramer A \& Brown SA 2012 Distinct roles of DBHS family members in the circadian transcriptional feedback loop. Molecular and Cellular Biology 32 4585-4594. (https://doi.org/10.1128/MCB.00334-12)

Kowalska E, Ripperger JA, Hoegger DC, Bruegger P, Buch T, Birchler T, Mueller A, Albrecht U, Contaldo C \& Brown SA 2013 NONO couples the circadian clock to the cell cycle. PNAS 110 1592-1599. (https://doi. org/10.1073/pnas.1213317110)

Krol J 2017 Paraspeckles: nuclear nests helping to raise mature miRNAs. Nature Structural and Molecular Biology 24 783-784. (https://doi org/10.1038/nsmb.3479)

Kuwahara S, Ikei A, Taguchi Y, Tabuchi Y, Fujimoto N, Obinata M, Uesugi S \& Kurihara Y 2006 PSPC1, NONO, and SFPQ are expressed in mouse Sertoli cells and may function as coregulators of androgen receptormediated transcription. Biology of Reproduction 75 352-359. (https:// doi.org/10.1095/biolreprod.106.051136)

Li S, Kuhne WW, Kulharya A, Hudson FZ, Ha K, Cao Z \& Dynan WS 2009 Involvement of p54(nrb), a PSF partner protein, in DNA double-strand break repair and radioresistance. Nucleic Acids Research 37 6746-6753. (https://doi.org/10.1093/nar/gkp741)

Li S, Li Z, Shu FJ, Xiong H, Phillips AC \& Dynan WS 2014 Doublestrand break repair deficiency in NONO knockout murine embryonic fibroblasts and compensation by spontaneous upregulation of the PSPC1 paralog. Nucleic Acids Research 42 9771-9780. (https://doi. org/10.1093/nar/gku650)

Li Y, Li Y, Chen W, He F, Tan Z, Zheng J, Wang W, Zhao Q \& Li J 2015 NEAT expression is associated with tumor recurrence and unfavorable prognosis in colorectal cancer. Oncotarget 6 27641-27650. (https://doi. org/10.18632/oncotarget.4737)

Li R, Harvey AR, Hodgetts SI \& Fox AH 2017 Functional dissection of NEAT1 using genome editing reveals substantial localization of the NEAT1_1 isoform outside paraspeckles. RNA 23 872-881. (https://doi. org/10.1261/rna.059477.116)

Liang S \& Lutz CS 2006 p54nrb is a component of the snRNP-free U1A (SFA) complex that promotes pre-mRNA cleavage during polyadenylation. RNA 12 111-121. (https://doi.org/10.1261/rna.2213506)

Loveland KL, Herszfeld D, Chu B, Rames E, Christy E, Briggs LJ, Shakri R, de Kretser DM \& Jans DA 1999 Novel low molecular weight microtubuleassociated protein-2 isoforms contain a functional nuclear localization sequence. Journal of Biological Chemistry 274 19261-19268. (https:// doi.org/10.1074/jbc.274.27.19261)

Loveland KL, Major AT, Butler R, Young JC, Jans DA \& Miyamoto Y 2015 Putting things in place for fertilization: discovering roles for importin proteins in cell fate and spermatogenesis. Asian Journal of Andrology 17 537-544. (https://doi.org/10.4103/1008-682X.154310)

Lu JY \& Sewer MB 2015 p54nrb/NONO regulates cyclic AMP-dependent glucocorticoid production by modulating phosphodiesterase mRNA splicing and degradation. Molecular and Cellular Biology 35 1223-1237. (https://doi.org/10.1128/MCB.00993-14)

Maier B \& Kramer A 2013 A NONO-gate times the cell cycle. PNAS 110 1565-1566. (https://doi.org/10.1073/pnas.1221057110)

Major AT, Whiley PA \& Loveland KL 2011 Expression of nucleocytoplasmic transport machinery: clues to regulation of spermatogenic development. Biochimica and Biophysica Acta 1813 1668-1688. (https://doi. org/10.1016/j.bbamcr.2011.03.008)

Major AT, Hogarth CA, Miyamoto Y, Sarraj MA, Smith CL, Koopman P, Kurihara Y, Jans DA \& Loveland KL 2015 Specific interaction with the nuclear transporter importin alpha2 can modulate paraspeckle protein
1 delivery to nuclear paraspeckles. Molecular Biology of the Cell $\mathbf{2 6}$ 1543-1558. (https://doi.org/10.1091/mbc.E14-01-0678)

Major AT, Miyamoto Y, Lo CY, Jans DA \& Loveland KL 2017 Development of a pipeline for automated, high-throughput analysis of paraspeckle proteins reveals specific roles for importin alpha proteins. Scientific Reports 7 43323. (https://doi.org/10.1038/srep43323)

Meehan T, Schlatt S, O'Bryan MK, de Kretser DM \& Loveland KL 2000 Regulation of germ cell and Sertoli cell development by activin, follistatin, and FSH. Developmental Biology 220 225-237. (https://doi. org/10.1006/dbio.2000.9625)

Merlet J, Racine C, Moreau E, Moreno SG \& Habert R 2007 Male fetal germ cells are targets for androgens that physiologically inhibit their proliferation. PNAS 104 3615-3620. (https://doi.org/10.1073/ pnas.0611421104)

Miyamoto Y, Boag PR, Hime GR \& Loveland KL 2012 Regulated nucleocytoplasmic transport during gametogenesis. Biochimica and Biophysica Acta 1819 616-630. (https://doi.org/10.1016/j. bbagrm.2012.01.015)

Myojin R, Kuwahara S, Yasaki T, Matsunaga T, Sakurai T, Kimura M, Uesugi S \& Kurihara Y 2004 Expression and functional significance of mouse paraspeckle protein 1 on spermatogenesis. Biology of Reproduction 71 926-932. (https://doi.org/10.1095/biolreprod.104.028159)

Naganuma T \& Hirose T 2013 Paraspeckle formation during the biogenesis of long non-coding RNAs. RNA Biology 10 456-461. (https://doi. org/10.4161/rna.23547)

Naganuma T, Nakagawa S, Tanigawa A, Sasaki YF, Goshima N \& Hirose T 2012 Alternative 3 '-end processing of long noncoding RNA initiates construction of nuclear paraspeckles. EMBO Journal 31 4020-4034. (https://doi.org/10.1038/emboj.2012.251)

Nakagawa S \& Hirose T 2012 Paraspeckle nuclear bodies - useful uselessness? Cellular and Molecular Life Sciences 69 3027-3036. (https:// doi.org/10.1007/s00018-012-0973-x)

Nakagawa S, Naganuma T, Shioi G \& Hirose T 2011 Paraspeckles are subpopulation-specific nuclear bodies that are not essential in mice. Journal of Cell Biology 193 31-39. (https://doi.org/10.1083/ jcb.201011110)

Nakagawa S, Shimada M, Yanaka K, Mito M, Arai T, Takahashi E, Fujita Y, Fujimori T, Standaert L, Marine JC et al. 2014 The IncRNA Neat1 is required for corpus luteum formation and the establishment of pregnancy in a subpopulation of mice. Development 141 4618-4627. (https://doi. org/10.1242/dev.110544)

Namekawa SH, Park PJ, Zhang LF, Shima JE, McCarrey JR, Griswold MD \& Lee JT 2006 Postmeiotic sex chromatin in the male germline of mice. Current Biology 16 660-667. (https://doi.org/10.1016/j. cub.2006.01.066)

Nishimoto Y, Nakagawa S, Hirose T, Okano HJ, Takao M, Shibata S, Suyama S, Kuwako K, Imai T, Murayama S et al. 2013 The long noncoding RNA nuclear-enriched abundant transcript 1_2 induces paraspeckle formation in the motor neuron during the early phase of amyotrophic lateral sclerosis. Molecular Brain 6 31. (https://doi. org/10.1186/1756-6606-6-31)

Pan LJ, Zhong TF, Tang RX, Li P, Dang YW, Huang SN \& Chen G 2015 Upregulation and clinicopathological significance of long non-coding NEAT1 RNA in NSCLC tissues. Asian Pacific Journal of Cancer Prevention 16 2851-2855. (https://doi.org/10.7314/apjcp.2015.16.7.2851)

Patton JG, Porro EB, Galceran J, Tempst P \& Nadal-Ginard B 1993 Cloning and characterization of PSF, a novel pre-mRNA splicing factor. Genes and Development 7 393-406. (https://doi.org/10.1101/gad.7.3.393)

Peng R, Dye BT, Perez I, Barnard DC, Thompson AB \& Patton JG 2002 PSF and p54nrb bind a conserved stem in U5 snRNA. RNA 8 1334-1347. (https://doi.org/10.1017/s1355838202022070)

Prasanth KV, Prasanth SG, Xuan Z, Hearn S, Freier SM, Bennett CF, Zhang MQ \& Spector DL 2005 Regulating gene expression through RNA nuclear retention. Cell 123 249-263. (https://doi.org/10.1016/j. cell.2005.08.033)

Rajesh C, Baker DK, Pierce AJ \& Pittman DL 2011 The splicing-factor related protein SFPQ/PSF interacts with RAD51D and is necessary for homology-directed repair and sister chromatid cohesion. Nucleic Acids Research 39 132-145. (https://doi.org/10.1093/nar/gkq738)

Rogakou EP, Pilch DR, Orr AH, Ivanova VS \& Bonner WM 1998 DNA double-stranded breaks induce histone $\mathrm{H} 2 \mathrm{AX}$ phosphorylation on 
serine 139. Journal of Biological Chemistry 273 5858-5868. (https://doi. org/10.1074/jbc.273.10.5858)

Rosonina E, Ip JY, Calarco JA, Bakowski MA, Emili A, McCracken S, Tucker P, Ingles CJ \& Blencowe BJ 2005 Role for PSF in mediating transcriptional activator-dependent stimulation of pre-mRNA processing in vivo. Molecular and Cellular Biology 25 6734-6746. (https://doi. org/10.1128/MCB.25.15.6734-6746.2005)

Russell LD 1990 Histological and Histopathological Evaluation of the Testis. St. Louis, MO: Cache River Press.

Salvador F \& Gomis RR 2018 Paraspeckle factor turns TGF-beta1 prometastatic. Nature Cell Biology 20 367-369. (https://doi.org/10.1038/ s41556-018-0078-3)

Sasaki YT, Ideue T, Sano M, Mituyama T \& Hirose T 2009 MENepsilon/ beta noncoding RNAs are essential for structural integrity of nuclear paraspeckles. PNAS 106 2525-2530. (https://doi.org/10.1073/ pnas.0807899106)

Shav-Tal Y \& Zipori D 2002 PSF and p54(nrb)/NonO - multi-functional nuclear proteins. FEBS Letters 531 109-114. (https://doi.org/10.1016/ s0014-5793(02)03447-6)

Shelkovnikova TA, Robinson HK, Troakes C, Ninkina N \& Buchman VL 2014 Compromised paraspeckle formation as a pathogenic factor in FUSopathies. Human Molecular Genetics 23 2298-2312. (https://doi. org/10.1093/hmg/ddt622)

Shelkovnikova TA, Kukharsky MS, An H, Dimasi P, Alexeeva S, Shabir O, Heath PR \& Buchman VL 2018 Protective paraspeckle hyper-assembly downstream of TDP-43 loss of function in amyotrophic lateral sclerosis. Molecular Neurodegeneration 13 30. (https://doi.org/10.1186/s13024018-0263-7)

Shima JE, McLean DJ, McCarrey JR \& Griswold MD 2004 The murine testicular transcriptome: characterizing gene expression in the testis during the progression of spermatogenesis. Biology of Reproduction $\mathbf{7 1}$ 319-330. (https://doi.org/10.1095/biolreprod.103.026880)

Smith LB, Walker WH \& O'Donnell L 2015 Hormonal regulation of spermatogenesis through Sertoli cells by androgens and estrogens. Sertoli Cell Biology 175-200. (https://doi.org/10.1016/C2013-0-01369-2)

Souquere S, Beauclair G, Harper F, Fox A \& Pierron G 2010 Highly ordered spatial organization of the structural long noncoding NEAT1 RNAs within paraspeckle nuclear bodies. Molecular Biology of the Cell 21 4020-4027. (https://doi.org/10.1091/mbc.E10-08-0690)

Standaert L, Adriaens C, Radaelli E, Van Keymeulen A, Blanpain C, Hirose T, Nakagawa S \& Marine JC 2014 The long noncoding RNA Neat1 is required for mammary gland development and lactation. RNA 20 1844-1849. (https://doi.org/10.1261/rna.047332.114)

Sunwoo H, Dinger ME, Wilusz JE, Amaral PP, Mattick JS \& Spector DL 2009 MEN epsilon/beta nuclear-retained non-coding RNAs are upregulated upon muscle differentiation and are essential components of paraspeckles. Genome Research 19 347-359. (https://doi.org/10.1101/ gr.087775.108)

Turner JM, Aprelikova O, Xu X, Wang R, Kim S, Chandramouli GV, Barrett JC, Burgoyne PS \& Deng CX 2004 BRCA1, histone H2AX phosphorylation, and male meiotic sex chromosome inactivation. Current Biology 14 2135-2142. (https://doi.org/10.1016/j.cub.2004.11.032)

Turner JM, Mahadevaiah SK, Ellis PJ, Mitchell MJ \& Burgoyne PS 2006 Pachytene asynapsis drives meiotic sex chromosome inactivation and leads to substantial postmeiotic repression in spermatids. Developmental Cell 10 521-529. (https://doi.org/10.1016/j.devcel.2006.02.009)

Wang L \& Zhu H 2018 Long noncoding nuclear paraspeckle assembly transcript 1 acts as prognosis biomarker and increases cell growth and invasion in cervical cancer by sequestering microRNA101. Molecular Medicine Reports 17 2771-2777. (https://doi.org/10.3892/ mmr.2017.8186)

West JA, Mito M, Kurosaka S, Takumi T, Tanegashima C, Chujo T, Yanaka K, Kingston RE, Hirose T, Bond C et al. 2016 Structural, super-resolution microscopy analysis of paraspeckle nuclear body organization. Journal of Cell Biology 214 817-830. (https://doi.org/10.1083/jcb.201601071)

Wilusz JE, JnBaptiste CK, Lu LY, Kuhn CD, Joshua-Tor L \& Sharp PA 2012 A triple helix stabilizes the $3^{\prime}$ ends of long noncoding RNAs that lack poly(A) tails. Genes and Development 26 2392-2407. (https://doi. org/10.1101/gad.204438.112)

Wu Y, Yang L, Zhao J, Li C, Nie J, Liu F, Zhuo C, Zheng Y, Li B, Wang Z et al. 2015 Nuclear-enriched abundant transcript 1 as a diagnostic and prognostic biomarker in colorectal cancer. Molecular Cancer 14191. (https://doi.org/10.1186/s12943-015-0455-5)

Yamazaki T, Souquere S, Chujo T, Kobelke S, Chong YS, Fox AH, Bond CS, Nakagawa S, Pierron G \& Hirose T 2018 Functional domains of NEAT1 architectural IncRNA induce paraspeckle assembly through phase separation. Molecular Cell 70 1038-1053.e7. (https://doi.org/10.1016/j. molcel.2018.05.019)

Yarosh CA, lacona JR, Lutz CS \& Lynch KW 2015 PSF: nuclear busy-body or nuclear facilitator? Wiley Interdiscip Rev RNA 6 351-367. (https://doi. org/10.1002/wrna.1280)

Yeh HW, Hsu EC, Lee SS, Lang YD, Lin YC, Chang CY, Lee SY, Gu DL, Shih JH, Ho CM et al. 2018 PSPC1 mediates TGF-beta1 autocrine signalling and Smad2/3 target switching to promote EMT, stemness and metastasis. Nature Cell Biology 20 479-491. (https://doi.org/10.1038/ s41556-018-0062-y)

You J, Zhang Y, Liu B, Li Y, Fang N, Zu L, Li X \& Zhou Q 2014 MicroRNA449 a inhibits cell growth in lung cancer and regulates long noncoding RNA nuclear enriched abundant transcript 1. Indian Journal of Cancer $\mathbf{5 1}$ (Supplement 3) e77-e81. (https://doi.org/10.4103/0019-509X.154055)

Zeng C, Xu Y, Xu L, Yu X, Cheng J, Yang L, Chen S \& Li Y 2014 Inhibition of long non-coding RNA NEAT1 impairs myeloid differentiation in acute promyelocytic leukemia cells. BMC Cancer 14 693. (https://doi. org/10.1186/1471-2407-14-693)

Zhang Z \& Carmichael GG 2001 The fate of dsRNA in the nucleus: a p54(nrb)-containing complex mediates the nuclear retention of promiscuously A-to-I edited RNAs. Cell 106 465-475. (https://doi. org/10.1016/s0092-8674(01)00466-4)

Zhao W, An Y, Liang Y \& Xie XW 2014 Role of HOTAIR long noncoding RNA in metastatic progression of lung cancer. European Review for Medical and Pharmacological Sciences 18 1930-1936.

Zhou X, Kudo A, Kawakami H \& Hirano H 1996 Immunohistochemical localization of androgen receptor in mouse testicular germ cells during fetal and postnatal development. Anatomical Record 245 509-518. (https://doi.org/10.1002/(SICl)1097-0185(199607)245:3<509::AIDAR7>3.0.CO;2-M)

Received 9 April 2019

First decision 3 June 2019

Revised manuscript received 28 June 2019

Accepted 12 July 2019 